\title{
MANA AHA? EXPLORING THE USE OF MANA IN THE LEGAL MĀORI CORPUS
}

\author{
Mary Boyce*
}

\begin{abstract}
The Legal Māori Corpus (LMC) is one of several major outputs of the Legal Mãori Project, and provides the core evidence for the compilation of the Legal Māori Dictionary, due to be completed in 2012. To our knowledge it is the largest publicly available corpus of te reo Mãori. The LMC is comprised of 8 million words of running text, compiled from printed legal texts in te reo Māori spanning from the 1820s to the current day. The pre-1910 text collection (5.2 million words) from the LMC is now publicly available on the Victoria University of Wellington Law Faculty website. Those remaining texts (1.8 million words printed from 1910 onwards) that are able to be cleared of copyright and confidentiality restrictions will be released in 2012. This paper briefly outlines the context of the Legal Māori Project, describes the compilation and structure of the LMC, and then focuses in detail on the use of the word mana in the corpus. It identifies the common collocations and phrases that contain mana, and looks at their distribution over time.
\end{abstract}

\section{INTRODUCTION}

Ko tōku reo, ko tōku mana: in my language is my power, my prestige, my effectiveness.

Language and the law are inextricably linked. In the legal domain it is crucial that there is a crisp and precise understanding of the words used to express legal ideas. Such precision enables the effective performance of the law. When the law of one culture interacts with that of another, the possibilities for misunderstanding are significant. Each system of law carries with it the cultural paradigm it is derived from. Each system has its customary terms and associated meanings. It is where these overlap that the need to clarify and disambiguate legal terms becomes a most challenging task.

\footnotetext{
Legal Māori Project, Law Faculty, Victoria University of Wellington; Department of Indo-Pacific Languages and Literatures, University of Hawai'i at Mānoa. The Legal Māori Project is led by Māmari Stephens of the Victoria University of Wellington Law Faculty, and Mary Boyce of the Department of IndoPacific Languages and Literatures at the University of Hawai'i at Mānoa. Māori words in this paper which appeared in quoted material with umlauts over vowels have been corrected to show macrons to confirm to the current orthographic conventions.
} 
Such is the case with terms in Māori for Western legal concepts, and their emergence in the context of contact with both the English language and the English legal system in New Zealand since colonisation in the 19th century. The Legal Māori Project aims to identify and investigate Māori legal terms and the Māori language of law. Perhaps the most daunting challenge is in teasing out the use of indigenous terms for customary legal practices and concepts and how these may have morphed when used to express legal ideas in the new colony, and changed again over time as the country developed.

Mana is one such customary concept used in the legal domain. The use of the word mana in the Legal Māori Corpus (LMC) is explored here, including its frequency and its collocations or patterns of use.

\section{THE LEGAL MĀORI PROJECT}

The Legal Māori Project, conceived of by Māmari Stephens and based at the Victoria University of Wellington Law Faculty is a project with four major outputs: the Legal Māori Archive, the Legal Māori Lexicon, the LMC and the Legal Māori Dictionary. The first three of these are now publicly available. The key aim of the Legal Māori Project is to identify and investigate terms used in Māori to convey Western legal concepts, and further, to identify and record a shared legal vocabulary for legal professionals and others.

The Legal Māori Archive/He Pātaka Kupu Ture makes available a large collection of full written legal texts in Māori, in digital form for easy access by anyone with interest in them. ${ }^{1}$ The archive includes texts published prior to 1910 and was launched in June 2009.

The Legal Māori Lexicon is a list of legal terms with English glosses. ${ }^{2}$ The terms were identified in a range of ways. Methods included dictionary searches, extensive reading of legal texts, and the compilation and analysis of the Legal Māori Corpus. ${ }^{3}$ The Legal Māori Lexicon forms the basis of the headword list for the dictionary; it was made publicly available in June 2010.

The manuscript of the Legal Māori Dictionary will be completed in 2012. It will contain Māori legal terms and their meanings in English, together with examples of use in Māori from the LMC. ${ }^{4}$

1 "He Pātaka Kupu Ture/Legal Māori Archive" New Zealand Electronic Text Centre <www.nzetc.org> [Legal Māori Archive].

2 Māmari Stephens "The Legal Māori Lexicon" (2010) Victoria University of Wellington <www.victoria.ac.nz/law>.

3 For further details of the identification of legal terms within the corpus see: Māmari Stephens "Wrestling with the Taniwha: an analysis of two Māori language texts and engagement with Western legal concepts" (2008) 14 Revue Juridique Polynesienne 135 ["Wresting with the Taniwha"].

4 For a concise description of the corpus, see Mary Boyce "The Legal Māori Corpus" (2010) Victoria University of Wellington <www.victoria.ac.nz/law>. 
The project team is currently working on the entries for the dictionary. Because of their complexity, special attention is being given to legal terms derived from customary concepts.

As a prelude to the discussion of the patterns of occurrence of the word mana in written legal texts, a brief outline of the design and compilation of the LMC follows. Some historical data on the word mana is then presented. The patterns of occurrence of mana in written texts in Māori from the legal domain over a time frame of some 150 years are then explored.

\section{THE LEGAL MATORI CORPUS}

\section{A Data to Inform a Dictionary Entry: Compile a Corpus}

Entries in contemporary dictionaries are typically based on information from large collections of authentic texts. These collections are known as corpora (corpus in the singular). In compiling a dictionary, lexicographers first compile a corpus, and then identify the individual words in that corpus (the types) and how often each of those words occurs (the tokens). This process assists them in deciding which words should be headwords in their dictionary, and which meanings of those words should be covered in the headword entry. Each headword is then examined in terms of its context of occurrence; this helps establish its collocations, or the words that typically co-occur with the target word.

\section{$B$ The Corpus}

The LMC is the largest known readily available corpus of Māori. In its entirety, it includes approximately 8 million words of running text compiled from published texts in Māori with a legal focus. The pre-1910 collection of texts in the LMC - those now clear of Crown copyright - is publicly available; this represents the larger proportion of the corpus (approximately 5.2 million words). The remaining texts are undergoing copyright and other clearances, and those that can be cleared for public access will be released in 2012 .

The corpus was designed to represent legal texts in Māori over time from the earliest written published texts through to the present. For a text to be eligible for inclusion, it had to be a written text and published for a readership of more than three people. The project team identified relevant sources and acquired the texts for the corpus in various ways. A valuable source of information on 19th century texts was Books in Māori. ${ }^{5}$ Other sources were identified by team members with legal training, and then those sources surveyed to select texts for acquisition for the corpus.

\section{Text Categories in the Legal Māori Corpus}

The project team collected the texts for the corpus in six categories, reflecting the range of text types in the legal domain in Māori. These categories are:

5 P Griffith and P Parkinson Books in Māori: 1815-1900, An Annotated Bibliography (Reed Publishing, Auckland, 2004). 
(1) Language of the Crown (these are government generated, for example speeches of Māori members of Parliament, circular letters and proclamations, and Native Affairs Committee reports)

(2) Māori community generated language (for example, petitions, letters to the Governor, evidence to commissions of inquiry)

(3) Statutory language (acts and bills)

(4) Language of agreement and obligation (deeds and contracts, leases, documents on native affairs and land purchasing)

(5) Court and tribunal language (for example, generated by courts, tribunals or royal commissions)

(6) Language of Māori governing bodies (for example, the Anglican synod or the Kotahitanga Parliament).

Generally the texts were taken in their entirety. One exception to this was Te Kähiti ${ }^{6}$ (the government gazette) which was sampled to maintain balance in the corpus; the volume of Te Kähiti texts would have overwhelmed the other texts in the corpus.

\section{Texts Grouped in Three Time Periods: pre-1910, 1910-1969 and 1970 onwards}

Users of the corpus are able to analyse the corpus in its entirety, or according to text category. It is also possible to analyse the corpus in time periods. The corpus has been arranged in three time periods for this purpose: texts published pre-1910, texts published between 1910 and 1969, and texts published 1970 to 2010. The time divisions were made according to the pattern of publication of legal texts in Māori over time. The middle period, from 1910 to 1969, was one where there was a movement away from production of legal texts in Māori in favour of publishing that material in English only. From 1970 there was a resurgence in the publication of legal (and other) texts in Māori.

Most of the selected texts were scanned, or photographed and rekeyed offshore; some of the more recent texts were gathered directly from websites (with permission). The photographed texts were typed twice by highly skilled copy typists, and the files then combined and inconsistencies between them checked and resolved to provide a high degree of accuracy (reportedly 98 per cent).

6 Legal Māori Archive, above n 1, at Te Kāhiti o Niu Tireni. 
Mark-up of text features was added, compliant with the international standards of the Text Encoding Initiative. $^{7}$

Tables which give details of the size of the whole corpus, and details of the size of the publicly available pre-1910 text collection by text category can be found on either the Victoria University of Wellington Law Faculty website or the New Zealand Electronic Text Centre website. ${ }^{8}$

\section{E Inconsistencies in the Corpus Texts}

While the corpus compilation process was a careful one, there remains some inconsistency in the corpus text files, and this affects the accurate calculation of types and tokens in the corpus. ${ }^{9}$ There are two main types of inconsistency in the corpus: introduced and inherent inconsistency. The introduced inconsistency derives from the processes used to digitise the texts for the corpus. The inherent inconsistency derives from the nature of the contributing texts. There are patterns evident in each type of inconsistency. Refinement of the corpus to address this issue as it affects the identification and analysis of legal language is ongoing.

\section{Introduced inconsistency}

The introduced inconsistency is a consequence of the sheer volume of the corpus. In a corpus of approximately 8 million tokens, it is to be expected that there will be a degree of error; to attain the desired volume of text within time and budget constraints it is inevitable that compromises have to be made.

In the photographed and scanned texts, the clarity of the photograph or scan can affect the accuracy of their rekeying. We have noticed that in some texts letters appear to have been substituted (for example, the letter $\mathrm{u}$ is sometimes rendered as the letter $\mathrm{n}$ ). There is inevitably a degree of human error when texts are rekeyed, even though the processes followed kept this to a minimum.

7 "The Text Encoding Initiative (TEI) is a consortium which collectively develops and maintains a standard for the representation of texts in digital form. Its chief deliverable is a set of Guidelines which specify encoding methods for machine-readable texts, chiefly in the humanities, social sciences and linguistics. Since 1994, the TEI Guidelines have been widely used by libraries, museums, publishers, and individual scholars to present texts for online research, teaching, and preservation." See "TEI: Text Encoding Initiative" (2011) Text Encoding Initiative <www.tei-c.org>.

8 Boyce "The Legal Māori Corpus", above n 4.

9 "Types" are distinct or individual words, and "tokens" are each instance of those words in a text or corpus. For example, the word "the" is a type, and it will occur approximately once in every ten words (or 10 per cent of tokens) in a text of English. It is the most frequent word type of English. The type "te", meaning "the, singular", is the most frequent word of Māori. 


\section{Inherent inconsistency}

The inherent inconsistency includes issues associated with the development of orthography and spelling over time, the representation of dialect pronunciations in the spelling of words, and the use of punctuation features such as hyphens. It is predictable that there will be variance in orthography and spelling in a written corpus of Māori, compiled of texts published over a more than a century. The orthography for Māori was first developed in the 1820s, and it has undergone various changes as it matured and stabilised. Some refinements to, and standardisation of, the orthography are still occurring.

\section{F Changes in Orthography Over Time}

A proportion of the inconsistency in the spelling of individual words is the result of changes in orthography over time; these include the marking, or not, of vowel length, the assignment of word boundaries, and variation in the spelling of gainwords from English.

In early texts, vowel length was typically not marked. In some texts the double vowel system is used, and in more recent texts macrons are typically used. So, the words "marama" ("moon") and "mārama" ("clear") would both have been written as marama in older texts; maarama is the doublevowel version of mārama. In the LMC, the word for "court" can be found spelled as "kooti", "koti", and "kōti". 10

Word boundaries are another source of inconsistency. In earlier texts in particular, it is common for words that would today be written as individual words to be written without word breaks, for example onga for o ngā, kite for ki te, kia for ki a. This word boundary inconsistency is most obvious in the function words, ${ }^{11}$ but does affect some content words. ${ }^{12}$ The word boundary inconsistency in early texts has not been corrected, as the corpus aims to represent these texts as they were published. Also, the problem in these texts is principally found in the function words, which are not the key focus of our project. (We discovered that the process of downloading the digital versions of some contemporary texts from their website of origin resulted in all word boundaries being deleted from parts of the text such as captions for photographs; this is an example of introduced inconsistency, and these errors have been corrected when located.)

10 Raw counts of the frequency of each spelling, unanalysed as yet for meanings, show: "kooti" $(18,174$ occurrences), "koti" (342 occurrences) and "kōti" (1661 occurrences). The spelling "koti" will include a number that mean "coat" or "to divide", as well as those that mean "court".

11 Function words are the small connecting words that convey grammar and function (words such as te, i, ki, a, o, mā, nō).

12 Content words are those that carry lexical meaning (words like "whare" ("house, building"), "ture" ("law"), "kōti" ("court"), "kaiwhakawā" ("judge")). 
There is inconsistency in the use of hyphens in some items. The use, or not, of hyphens is a feature of proper nouns such as the names of places, people, institutions and in titles, but may also be present in compound words. The use of a hyphen to connect items with the prefix $\bar{a}-$ is another environment for inconsistency. The term for "district court" could be written in at least three ways; the first is the accepted contemporary spelling following the Te Taura Whiri i te Reo Māori (Māori Language Commission) Orthographic Conventions: ${ }^{13}$ kōti ā-rohe, kōti-ā-rohe, kōti ā rohe. To each of these can be added the forms written with no vowel length marking (for example koti-a-rohe), or with double vowels to indicate length (kooti-aa-rohe).

A further category of inconsistency is that of representing different regional pronunciations in the spelling of words. A typical example of this feature is the early use of $w$ for the digraph wh, so that wa is the spelling used for the word spelled as "whā" ("four") nowadays. The word form wa might also represent the word "wā" ("time"), or the dialect representation of the possessive $\bar{a}$, as in ā tātou in contrast to wā tātou.

\section{$G$ Variation in the Spelling of Gainwords from English: the Case of Kāwanatanga}

Words that have entered the language from other languages, typically English, often exhibit some variance in their spellings. In the LMC, the word "kāwanatanga" ("government") provides an example of a word with clear legal meaning that was found with a range of spellings in the corpus. ${ }^{14}$ Several of the spellings are examples of typical variation found in words of English origin, for example, kāwanatanga: kāwanaranga (variance in the form of the nominal suffix -canga), kāwanataka / kawanataka (Ngāi Tahu dialect, with and without macrons), kāwanatana / kawanatana (Tūhoe dialect, with and without macrons).

Some are more likely to be errors, as shown in Table 1:

\section{Table 1: Examples of error with the word kāwanatanga}

\begin{tabular}{|l|l|}
\hline macron placement: & kāwanatangā, kāwānatanga \\
\hline letter substitution: & kawanatonga, kawanatangu, kāwanatange \\
\hline typing error: & kawanataga, kāwanatange, kāwanantanga \\
\hline word space missing: & kāwanatangae, kāwanatangai, kāwanatangakua \\
\hline
\end{tabular}

13 Te Taura Whiri "Māori Orthographic Conventions" (2011) Māori Language Commission <www.tetaurawhiri.govt.nz>.

14 The data presented here are from the corpus texts published 1910 onwards only. 


\section{H The Spelling Standards Used for the Legal Māori Project}

To summarise, the orthography of Māori is less than 200 years old. It has changed over time, and while it is more stable nowadays, it is still subject to change and a degree of inconsistency. Te Taura Whiri i te Reo Māori (the Māori Language Commission) sets the standard for contemporary spelling, and posts its most recent orthographic conventions online. These conventions have been adopted by the Legal Māori Project for the dictionary manuscript. The corpus, however, maintains the spellings used in the original texts as published.

\section{HISTORY OF THE WORD MANA}

The word mana is used throughout Polynesia to signify a core cultural force which is rendered in English variously as power, authority, prestige and effectiveness. Hirini Moko Mead, in his book Tikanga Māori: Living by Mãori Values, explains that there is "high value placed upon mana", that mana is typical of leaders, and leaders are typically from prominent families. ${ }^{15}$ Mana is an integral part of the kinship system and can be traced through lines of descent. He explains further that mana and tapu are closely linked. Every person is born with mana, and this mana can increase or decrease throughout life, and so is affected by an individual's deeds and how these are regarded in the community as well as deriving from an individual's birthright. Mana depends on others. "[Mana] can be described as the creative and dynamic force that motivates an individual to do better than others". ${ }^{16}$

Mana has a long history. The word for the idea emerged deep in the past. Researchers at $\mathrm{Te}$ Mātāhauariki Institute, Waikato University, New Zealand, worked to establish a solid pool of evidence on traditional Māori legal order by compiling "the historical uses and meanings of selected terms and concepts from Maori customary law" from both written and spoken sources: ${ }^{17}$

A major undertaking by Te Mātāhauariki is the production of Te Mātāpunenga - a compendium of historical references to key Māori customary legal concepts. This is based on a thorough exploration of historical materials, many of which have lain unnoticed for decades in archives and private collections, and brings together references to customary concepts and institutions which appear to come from influential or authoritative sources and throw light on both historical and contemporary meanings of these ideas and the means for implementing them.

15 H Mead Tikanga Māori: Living by Mãori Values (Huia Publications, Wellington, 2003) at 29.

16 Ibid, at 45-52, particularly at 51.

17 R Benton "Te Mātāpunenga: Introducing the Titles" (2004) 8 Te Mātāhauariki Newsletter. 
Part of this work involved tracing the emergence of words over time. Benton traces the emergence of the word mana to the Proto-Oceanic period, step three of a twelve step process of lexical development culminating in contemporary Māori: ${ }^{18}$

A further critical point in the dispersal of Austronesian languages took place as Austronesian speakers began to spread out along the Northeast New Guinea towards the western Pacific. Māori words traceable to this period include:

Mana - Authority, control; influence, prestige, power; psychic force; vested with effective authority, from *mana, "Power, effectiveness, prestige".

In 1891, Tregear published a dictionary comparing the vocabulary of Māori with those of Polynesian languages. He lists meanings for mana in the following Polynesian languages: Māori, Samoan, Tahitian, Hawaiian, Tongan, Rarotongan, Marquesan, Mangarevan, Paumotan (and also in Fijian, Malagasy, Malay, Sikayana). His definition for mana as it is used in Māori is as follows: ${ }^{19}$

MANA, authority; having authority, influence, prestige 2. Supernatural power; divine authority; having qualities which ordinary persons or things do not possess 3. Effectual, effective.

The definition of mana in the seventh (and current) edition of the Williams dictionary, published in 1971 , is very similar to these previous definitions: ${ }^{20}$

\section{Mana (i)}

1. n. Authority, control. 2. Influence, prestige, power. 3. Psychic force. 4. a. Effectual, binding, authoritative. 5. Having influence or power. 6. Vested with effective authority. 7. v.i. Be effectual, take effect. 8. Be avenged.

It can be seen that definitions in English of mana have remained consistent across time.

Published dictionary definitions in Māori are more recent. The first monolingual dictionaries of Māori have appeared only in the past five years. Tirohia Kimihia, ${ }^{21}$ published in 2006, is designed

18 R Benton "The Importance of Words: an Introduction" in T Adams, R Benton, A Frame, P Meredith, N Benton, and T Karena Te Mātāpunenga: A Compendium of References to Concepts of Māori Customary Law - Te Mātāhauariki Research Institute Occasional Papers Series (2003) vol 9 <www.lianz.waikato.ac.nz>.

19 E Tregear Māori-Polynesian Comparative Dictionary (Lyon and Blair, Wellington, 1891) at 203.

20 HW Williams A Dictionary of Māori (7th ed, Legislation Direct, Wellington, 2003).

21 Te Tāhuhu o te Mātauranga/New Zealand Ministry of Education Tirohia Kimihia: he kete wherawhera. (Lexis Nexis, Wellington, 2006). Huia Te Manu Tuku Kōrero is the first monolingual dictionary of Māori to be published. Its definitions:

mana 1 . Ki te mana tētahi mea ka whakaaetia. 2. Ko te mana te āhuatanga e kī ana kei te rangatira te kōrero whakamutunga. 
for young learners in immersion education. Its definitions of mana are minimal as is appropriate for the target audience. He Pātaka Kupu, ${ }^{22}$ published in 2008 , is a comprehensive dictionary for adults. Its definitions of mana are fuller and appear to be based largely on the earlier definitions in the Williams dictionary; it includes examples of use from authentic texts. ${ }^{23}$

The word mana has moved into the lexicon of several varieties of English; it is listed as a headword in contemporary dictionaries of British, American and New Zealand English. Over time and across languages the meanings of words, and the words they typically occur with, are subject to change. The word kiwi as it is used in New Zealand English provides a good example of this change across languages. In Māori, the word refers to the iconic New Zealand native bird, or its feathers as used in highly prized cloaks. In New Zealand English however, the word refers less frequently to the bird than to the New Zealand dollar, New Zealanders, or the kiwi fruit. ${ }^{24}$

The entry for mana in the 2005 edition of the New Zealand Oxford Dictionary, based on its use as a word of New Zealand English, indicates that it has maintained its traditional meaning, at least in dictionary definitions. It has the following glosses: ${ }^{25}$

mana 1. chiefly NZ power, control, influence; authority; prestige, charisma. 2. (in general Polynesian and Melanesian belief) the supernatural power pervading a person or thing.

Mana is given a whole column in the Oxford Dictionary of New Zealand English. ${ }^{26}$ Orsman traces its use in English, giving examples of its use over time. The earliest citation "in Maori contexts" is from 1843. In "non-Māori contexts" the earliest citation given is 1856.

22 Te Taura Whiri i te Reo Māori He Pātaka Kupu: te kai a te rangatira (Raupo, Auckland, 2008). The definitions:

mana 1. Te tū rangatira e tautokona ana, e whakaaetia ana e ètahi atu; te kaha ki te ārahi, ki te tohutohu i êtahi atu. 2. Te kaha e taea ai ngā whakaaro, ngā mahi rānei a tētahi atu te whakarerekē, te whakawai. 3. He kaha nō roto tonu i te tangata, nō te wairua, nō te hinengaro o te tangata. ... 4. E whai take ana, e pūmau ana i runga i ngā tikanga o te iwi, me te titiro a te nui tangata, e kore e turakina e wai rānei. 5. Ka puta ōna hua, ka whakatinanatia (o te kupu). 6. Ka utua tētahi hara, ka ngakina rānei tētahi mate.

23 Note that the definitions given in Māori in these footnotes are not translated, as it is preferred the reader access them in the original language, rather than through translation as is the case with the definitions that are in bilingual dictionaries or descriptions and explanations of mana written in English. Similarly, see the examples from the Legal Māori Corpus later in this paper.

24 For a detailed examination of words of Māori origin in New Zealand English, see J Macalister "The presence of Maori words in New Zealand English" (PhD Thesis, Victoria University of Wellington, 2003).

25 T Deverson and G Kennedy (eds) New Zealand Oxford Dictionary (Oxford University Press, Oxford, 2005) at 679 .

26 HW Orsman Dictionary of New Zealand English (Oxford University Press, Auckland, 1997) at 465. 
Mana remains highly relevant both in contemporary Māori and Polynesian societies, and in the wider nation-states of the Pacific. The frequent use of the word mana today, in both general and legal texts in te reo Māori, ${ }^{27}$ and in texts in New Zealand English ${ }^{28}$ indicates that mana as a core cultural value and driving principle maintains its currency and relevance today both within and beyond the Māori community. The following recent examples show this in both informal and formal contexts:

Mana is often mentioned in everyday contexts in New Zealand. Mead, aligning traditional ideas of mana with its application in contemporary times, mentions that if a tribal member was to be selected to play for the All Blacks (the prestigious New Zealand national rugby team) the mana of the whole tribe would be lifted. ${ }^{29}$ Following up on this idea, I searched Google for "All Blacks mana"; the search returned 65,800 hits (the examples given here are of the use of the word "mana" in English). One of these hits, a typical example of what can be found online, said the following: $:^{30}$

The All Blacks end 2010 with their mana enhanced. Playing an irresistible style of total rugby they have again swept all before them (bar that late Wallabies ambush in Hong Kong) and claimed pole position for the 2011 World Cup.

Another of these hits provided information on a recently published coffee table photographic book on the All Blacks, entitled Mana: Inside the All Blacks. ${ }^{31}$ In the online book blurb the link between mana and "tapu" (sacred), as described by Mead, is referenced: ${ }^{32}$

For the first time, a camera goes deep inside the sacred space of the All Black camp - revealing the highs and the lows, the pain and the passion, the commitment and the courage of New Zealand's iconic sporting team.

Sherry Rua, the granddaughter of Private Temata Rua, recently regained possession for the family of his medals which had been stolen. Her comments demonstrate the role of mana in contemporary times in the lives of Māori families. She said: ${ }^{33}$

27 Boyce, above n 4. Details of the frequency of "mana" in the Māori Broadcast Corpus and the Legal Māori Corpus are given in later in this paper.

28 "Mana" is one of a large group of gainwords from Māori in New Zealand English; it appears as a headword in dictionaries of New Zealand English. "Mana" is glossed as "authority, prestige" in J Macalister (ed) $A$ Dictionary of Maori Words in New Zealand English (Oxford University Press, New York, 2005) at 65. "Mana" is also regularly found in contemporary dictionaries of British and American English.

29 Mead, above n 15, at 51.

30 H Turner "McCaw spearheads masterful All Blacks" (2010) ESPN Scrum <www.espnscrum.com>.

31 J Kerr and N Danziger Mana: Inside the All Blacks (Hodder, New Zealand, Auckland, 2010).

32 Ibid (emphasis added). 
[The medals] are beautiful. To me they represent what he's done for his country ... To have the medals back is like mana back to the family. It just gives us the presence of our grandfather.

In formal contexts (and in the examples cited, also a legal one), mana plays a key role in evidence underpinning claims to the Waitangi Tribunal. The acquisition, maintenance, loss and role of mana is, for example, mentioned repeatedly in the report on the Te Urewera claim. Here are just three examples of the many in the report: ${ }^{34}$

- $\quad$ "They explained their core values of mana (authority), whanaungatanga (kinship), and utu (reciprocity) the values by which they live, and have always lived."

- $\quad$ "Ko Toi te tangata tuatahi ki te taunaha i te rohe ki uta o te Moana a Toi' 'Toi was the first to proclaim his mana over the lands from the shores of Te Moana-a-Toi inland"

- "Mana: the exercise of authority - the protection of people, land, and resources."

Furthermore, there are explanations of the meaning of mana given on pages $85-86$ of the WAI 894 report.

These examples from the Waitangi Tribunal indicate the importance of mana in legal contexts. The Legal Māori Project collected examples such as these from a broad and representative range of legal texts, and is using them to create the dictionary entries in the Legal Māori Dictionary.

\section{MANA IN THE LEGAL MATORI CORPUS}

\section{A Finding Mana}

The word mana was searched for in the 8 million words in the LMC and looked at in a number of ways. Its overall frequency in the total corpus was discovered, then its frequency across the three time periods, and similarly its collocations. The corpus was interrogated using WordSmith Tools $5,{ }^{35}$ using the Wordlist and Concord tools. These tools recognise a word as a string of characters bounded by spaces. Unfortunately the tools cannot disambiguate identical forms.

When preparing for the analysis of the word mana, there were just two forms to be distinguished: mana and māna". ${ }^{36}$ The word "māna" ("for/by him or her") was spelled as "mana"

33 A Bradley "Private Bullet's Medals Come Home" The Dominion Post (Wellington, 22 December 2010) at A5.

34 Waitangi Tribunal Te Urewera pre-publication: Part 1 (WAI 894 2009) at 17, 22 and 75 respectively.

35 For details of the WordSmith suite of corpus tools, see Mike Scott "Mike Scott's Web" <www.lexically.net>. The software is developed by Mike Scott, and is distributed by Oxford University Press.

36 There is a variant spelling in the corpus of "māna" as "maana", but these did not present a problem for our analysis of "mana". 
(without a macron) in earlier texts. These occurrences had to be removed from the data set before analysis of the target use of mana could begin; unfortunately, there were very many occurrences to be manually sorted and culled.

The word form mana ranks as 56th most frequent word in the 8 million word LMC. It occurred 20,340 times. However, as mentioned above, this includes some occurrences which represent the word spelled nowadays as māna, as in for example "māna e whakahaere" ("she or he will manage (it)"), or "hei tamaiti whāngai māna" ("as a foster child for him or her"). Each of the 20,340 occurrences of mana was examined in context, and those that were instances of māna were deleted from the data set. This left 18,273 occurrences of the word "mana" ("power, authority, prestige"), and brought the rank of mana down to approximately the 60th most frequent item in the corpus wordlist. For the analysis that follows, personal and place names were omitted, but relevant titles (for example legal roles or legislation) were retained.

The 18,273 occurrences are being sampled and analysed to identify word senses and collocations for the dictionary entry for mana. These are being looked at closely with reference to the customary meanings of mana, as identified by Te Mātāhauariki. They are also being examined to identify potential new uses of the word in contemporary texts.

In this paper, preliminary work to identify collocations to the right of mana is described. Further, the occurrence over time of certain multiword items including mana is examined. Preliminary work on collocations to the left has begun, but this is not yet at a stage that can be reported on.

\section{B The Company that Mana Keeps: Collocations to the Right}

The data set of some 18,000 occurrences of mana was sorted to identify potential two-word expressions beginning with mana, and hence the title of the paper: Mana aha? There were 999 different content words occurring immediately to the right of mana which formed potential twoword lexical units. Just 60 of these occurred ten times or more, and only 26 of the 60 occurred 20 times or more. It was decided to focus on this group of 26 items for this paper. These are presented in Table 2.

Table 2: Mana aha? Two word units beginning with mana

\begin{tabular}{|l|l|l|}
\hline Tokens & mana & Word immediately to the right of mana \\
\hline 847 & mana & whakahaere \\
\hline 487 & mana & motuhake (o tētahi iwi/hapū) \\
\hline 332 & mana & katoa \\
\hline 289 & mana & tangata \\
\hline 289 & mana & whenua \\
\hline 257 & mana & kōkiri \\
\hline
\end{tabular}




\begin{tabular}{|c|c|c|}
\hline 212 & mana & takiwā \\
\hline 174 & mana & Tohu (Mātauranga o Aotearoa) \\
\hline 156 & mana & Māori \\
\hline 150 & mana & hoko \\
\hline 98 & mana & kore \\
\hline 72 & mana & whakahou \\
\hline 71 & mana & arotake \\
\hline 70 & mana & whakawā \\
\hline 59 & mana & tuku \\
\hline 52 & Mana & Whanonga (Kaipāho) \\
\hline 51 & mana & nui \\
\hline 48 & mana & tiaki \\
\hline 42 & mana & pōti \\
\hline 39 & mana & rangatira \\
\hline 38 & mana & tūturu \\
\hline 36 & mana & atua \\
\hline 32 & mana & pupuri \\
\hline 24 & mana & ture \\
\hline 21 & mana & whakatau \\
\hline 20 & mana & $\mathrm{tu}$ \\
\hline
\end{tabular}

The most frequently occurring collocation was mana with whakahaere (mana whakahaere) at 847 instances. The next most frequent was mana motuhake, and this collocation tended to extend to the right to include the name of a particular kin group (tribe or sub-tribe) as in "te mana motuhake o Tūhoe". Others that were clearly part of longer phrases included the names of institutions: "[Te] Mana Tohu Mātauranga o Aotearoa" ("the New Zealand Qualifications Authority"), "[Te] Mana Arotake" ("Audit New Zealand"), and "[Te] Mana Whanonga Kaipāho" ("the Broadcasting Standards Authority"). Work is continuing to identify the nature of other patterns to the right of mana.

Raw frequency alone is not adequate when deciding on frequency thresholds for dictionary data. Range, or the spread of tokens across the texts of a corpus, is also important. The following examples show that raw frequency can hide important information. The expressions mana whanonga and mana nui each occurred 52 times, but their range is different.

We have already noted that "mana whanonga" is part of a longer phrasal item, the name for "the Broadcasting Standards Authority". There is only one variant to the longer phrase: Te Mana 
Whanonga Pāho. Further examination found that mana whanonga occurred in only five of the corpus texts, and that these were all about the Broadcasting Standards Authority, and only in texts published 1970 and onwards. The expression does not occur more widely in the corpus, and not in any text published earlier than 1970 .

In contrast, the 52 instances of mana nui occurred across 28 of the corpus texts, and across all three time periods. The expression mana nui did not refer to a single entity. It can be queried whether this is a phrasal item or just a simple noun plus a modifier /adjective combination, as in for example the difference between he wharenui ("a meeting house"), and "he whare nui" ("a big house"). Reviewing the examples in context suggests however that "mana nui" does have specific legal meaning; it is used for "chief / final authority". ${ }^{37}$

Table 3: Examples of mana nui from the Legal Māori Corpus

\begin{tabular}{|l|l|}
\hline Corpus text & Example \\
\hline BIM1562Maor: & $\begin{array}{l}\text { i te mea ko te Paremete te mana nui kei runga i nga } \\
\text { mea katoa. }\end{array}$ \\
\hline NZPaV03NgaK: & e kore e pai kia hoatu tenei mana nui ki te Kai Tiaki \\
\hline NZPaV03NgaK: & na te whakahaere kino i enei mana nui \\
\hline WesRepo: & me hoatu he mana nui ki te Kaiwhakarite \\
\hline WesRepo: & i hoatu mana nui ki te Komihana \\
\hline SedWhai: & kei a ia te mana nui \\
\hline
\end{tabular}

Each of the examples in Table 3 is being similarly scrutinised to provide information for the dictionary entries.

\section{Mana whakahaere}

A scan of the examples of "mana whakahaere" (which can be rendered in English as something like "the right to manage" or "executive power") shows that this frequently collocates with groups or institutions, with one group being granted or ceding mana whakahaere to the other; information such as this can be helpful to dictionary users when looking for guidance for their production of te reo Māori in legal contexts.

\section{Table 4: Examples of extended collocations of mana whakahaere (spellings standardised)}

\begin{tabular}{l|l} 
mana whakahaere & a te Kāwanatanga
\end{tabular}

37 See Stephens, above n 3, for further detail on the significance of multiword expressions and specific legal meanings. 


\begin{tabular}{|c|c|}
\hline mana whakahaere & a Te Kōti Whenua Māori \\
\hline mana whakahaere & a te Kuini \\
\hline mana whakahaere & a Te Puni Kōkiri \\
\hline mana whakahaere & a Te Uri o Hau \\
\hline mana whakahaere & a te Ture \\
\hline mana whakahaere & $\overline{\mathrm{a}}$-iwi \\
\hline mana whakahaere & à-rohe \\
\hline mana whakahaere & i ngā taonga \\
\hline mana whakahaere & i ngā tikanga \\
\hline mana whakahaere & i ngā whenua (Māori) \\
\hline mana whakahaere & i ō rātou whenua \\
\hline mana whakahaere & i te awa \\
\hline mana whakahaere & i raro i te (mana o te) ture \\
\hline mana whakahaere & katoa \\
\hline mana whakahaere & kāwanatanga \\
\hline mana whakahaere & Māori \\
\hline mana whakahaere & motuhake \\
\hline mana whakahaere & o Environment Waikato / o Environment Bay of Plenty \\
\hline mana whakahaere & o Ingarangi \\
\hline mana whakahaere & o Ngāti Mutunga / o Ngāti Tūwharetoa \\
\hline mana whakahaere & o te Hāhi / o te Hinota \\
\hline mana whakahaere & o te Kāwanatanga \\
\hline mana whakahaere & o te Kōti Whenua Māori \\
\hline mana whakahaere & o te Poari \\
\hline mana whakahaere & UHF \\
\hline mana whakahaere & whakawā \\
\hline
\end{tabular}

A more thorough scan of the data identifies which groups are typically involved (for example the government, the Māori Land Court, various iwi and hapū), and what they are ceding or granting executive authority over (frequently land, but also less predictable commodities such as Ultra High Frequency radio waves). This sort of information can be further examined over time and changes in transactions plotted; the corpus is therefore also a valuable source of social, cultural, economic and political information beyond its immediate value for the lexicographers working on the dictionary entries for each headword. 


\section{The Distribution of Mana in the Legal Māori Corpus across Three Time Periods}

As an example of the value of examining words across time as a means of identifying changes in patterns of use, the occurrences of these two word mana expressions were investigated: mana whenua, and mana moana.

Firstly, the frequency of mana on its own was found in each of the three time periods:

\section{Table 5: Mana across time}

\begin{tabular}{|l|l|l|l|}
\hline Time period & $\begin{array}{l}\text { Mana (tokens of mana, } \\
\text { omitting māna and } \\
\text { place \& personal } \\
\text { names) }\end{array}$ & $\begin{array}{l}\text { Total tokens in LMC } \\
\text { (omitting numerals) }\end{array}$ & \% tokens (approx) \\
\hline before 1910 & 10,944 & $5,243,760$ & $0.21 \%$ \\
\hline $1910-1969$ & 1879 & 760,948 & $0.25 \%$ \\
\hline 1970 onwards & 5450 & $1,842,672$ & $0.30 \%$ \\
\hline
\end{tabular}

Table 5 presents the number of tokens of mana in each time period of the corpus, the total number of tokens by time period, and the percentage of tokens represented by mana. If we look at the right-hand column, occurrences of mana as an approximate percentage of all tokens, it can be seen that the use of mana in written texts has increased slightly over time. It must be mentioned that we have no information on spoken legal texts, and so cannot make any comment about its frequency of use when speaking in legal contexts.

The only point of comparison we have from a substantial corpus of Māori is the use of mana in the Māori Broadcast Corpus (MBC). ${ }^{38}$ This is not a corpus of specifically legal texts, nor is it a corpus of written texts, but it does provide robust information on the relative frequency of high frequency words in more general contexts. Mana is ranked as 141st most frequent word in the MBC; it occurs 921 times. This represents approximately 0.09 per cent of all the tokens in the MBC. Let us now look at the expressions mana whenua and mana moana in the LMC over the three time periods.

\section{Mana whenua}

Mana whenua appears 275 times in the LMC. It occurs across 75 different texts, mostly those published after 1970. It occurs 8 times across just seven texts in the pre-1910 collection, it does not

38 The MBC is a one million word corpus of spoken Māori from radio and television programmes broadcast in 1995 and 1996: Mary Boyce "A Corpus of Modern Spoken Māori" (PhD Thesis, Victoria University of Wellington, 2006). 
occur in the mid period. It occurs 267 times across 67 texts in the contemporary period; these are mostly Waitangi Tribunal reports.

\section{Table 6: Mana whenua across time}

\begin{tabular}{|l|l|l|}
\hline Time period & mana whenua & $\begin{array}{l}\text { Tokens in LMC by time period } \\
\text { (omitting numerals) }\end{array}$ \\
\hline before 1910 & 8 & $5,243,760$ \\
\hline $1910-1969$ & 0 & 760,948 \\
\hline 1970 onwards & 267 & $1,842,672$ \\
\hline
\end{tabular}

The early period has just 8 occurrences of mana whenua in 5.24 million tokens (or approximately 1.5 occurrences per million), and the post 1970 period has 267 occurrences in 1.84 million tokens (or 145.10 occurrences per million tokens). This clearly indicates a substantial increase in use of the term mana whenua in written legal texts post 1970, and especially in the context of discourse about the Treaty of Waitangi. As a comparison with more general discourse, there are 23 occurrences of mana whenua across 15 texts in the one million word spoken MBC.

\section{Mana moana}

Mana moana appears only four times in the whole LMC. It appears in four different texts, one in the mid period, and three in the contemporary period. It does not appear in the pre-1910 period. Mana moana appears seven times in the MBC, across five texts. If we consider only the contemporary period, we can compare the three occurrences in 1.84 million words (or 1.63 per million tokens) of written legal Māori from 1970 onwards, with 7 occurrences per million tokens of spoken broadcast Māori from 1995 and 1996, and wonder if it is the case that the term mana moana might be used more in spoken legal texts in Māori than in written ones.

At this stage the scope and funding of the Legal Māori Project does not allow for the design, compilation and analysis of a corpus of spoken legal texts in Māori. We are aware that the lack of spoken data is a gap in our data. This is a gap we wish to fill once this first phase of the Legal Māori Project is complete and the dictionary manuscript prepared.

\section{NEXT STEPS}

Analysis of the corpus data to inform the writing of dictionary entries continues. The entries are being written by team members who have both legal training and proficiency in Māori. The team is guided by the Legal Māori Project Steering Committee, a group with a range of expertise and experience in law, te reo Māori and lexicography; it includes native speakers of Māori.

The linguist on the team has no legal training, but provides corpus advice and analysis to the team as requested. Further analysis of the patterns of use of mana is underway, and includes work 
on collocations to the left of mana and exploration of the types of verbs that occur with it, and the agents of mana: who assigns it, who acquires it and who cedes it.

Ideally the Legal Māori Project will continue beyond 2012, provided further funding is secured. This will allow for the compilation of a corpus of spoken legal texts, fuller analysis of the content of the texts in the current LMC, and work towards an expanded database and description of legal terms in Māori and legal language in Māori more generally to identify and explain how people "talk law". 
